\title{
Chitinozoan biostratigraphy of the Upper Ordovician of Faulx-les-Tombes (central Condroz Inlier, Belgium)
}

\author{
Jan Vanmeirhaeghe * \\ Research Unit Palaeontology, Ghent University, Krijgslaan 281/S8, B-9000 Ghent, Belgium
}

Received 5 November 2004; received in revised form 22 May 2005; accepted 25 July 2005

\begin{abstract}
The chitinozoan biostratigraphy of the Upper Ordovician Vitrival-Bruyère and Fosses formations (Bois de Presles and Faulxles-Tombes members) in the Faulx-les-Tombes area (Condroz Inlier, Belgium) is documented. The Baltoscandian Spinachitina cervicornis and Conochitina rugata chitinozoan biozones are recognised, and possibly also the Fungochitina fungiformis and Tanuchitina bergstroemi zones. Correlation with the Cautley Mudstones Formation of the Avalonian type Ashgill area is done with the C. rugata and the Bursachitina umbilicata chitinozoan biozones and possibly also with the F. fungiformis and T. bergstroemi chitinozoan biozones. The correlation allows an accurate dating of both formations. The Vitrival-Bruyère Formation is shown to span a much larger time interval than previously thought. The combination of litho- and biostratigraphical results from this study and those from the Puagne Inlier (western Condroz Inlier) shows diachronic boundaries for both members of the Fosses Formation. At some time during the deposition of the rugata and umbilicata chitinozoan biozones, simultaneous deposition took place of calcareous shale in the Puagne Inlier and mottled mudstone on a deeper shelf position in the Faulx-les-Tombes area.
\end{abstract}

(C) 2006 Elsevier B.V. All rights reserved.

Keywords: biostratigraphy; chitinozoans; Condroz Inlier; diachronism; Faulx-les-Tombes; Upper Ordovician

\section{Introduction}

The Condroz Inlier, also known as the 'Bande de Sambre et Meuse', 'Bande condrusienne', 'Ride du Condroz' or 'Bande de Dave', is a narrow strip of Ordovician and Silurian, mainly siliciclastic sedimentary rocks, $65 \mathrm{~km}$ long and $0.5-4 \mathrm{~km}$ wide. It is situated in the northern part of the Variscan thrust front and is bordered by Devonian rocks of the Namur Synclinorium in the north and of the Dinant Synclinorium in the south (see Verniers et al., 2001, Fig. 2). The Condroz Inlier is

\footnotetext{
* Tel.: +32 9 2644612; fax: +3292644608.

E-mail address: Jan.Vanmeirhaeghe@UGent.be.
}

composed of at least four tectonic wedges, of which some were carried along the Midi Overthrust in the Variscan deformation front. For the purpose of this paper, only the allochtonous Puagne Inlier (with cleavage) in the southwest and the major parautochtonous central part (without cleavage) are mentioned (Fig. 1).

After some studies of dispersed outcrops in the nineteenth century, an overview of the stratigraphy of the Condroz Inlier was given by Malaise (1909a,b, 1910), Maillieux (1913, 1926) and by the extensive fieldwork by Michot (1928, 1934, 1944). The stratigraphy of most rocks of the Condroz Inlier was based on some graptolite finds, while other parts were dated with brachiopods and trilobites. Martin (1969) studied 


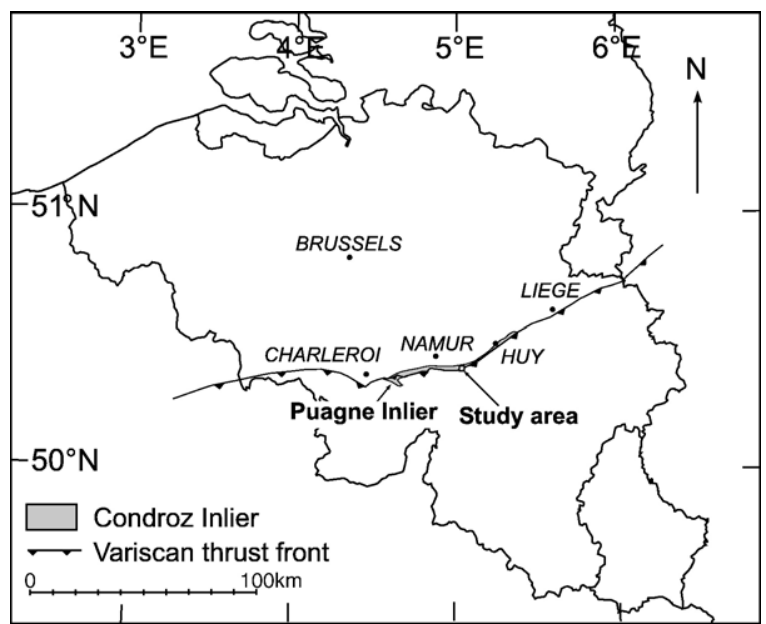

Fig. 1. Location of the Condroz Inlier (in grey) and the study area. In the west of the Condroz Inlier, the Puagne area is indicated.

acritarchs from all of the formations of the Condroz Inlier. These extensive acritarch data, however, did not allow a detailed biozonation. After this work, biostratigraphical studies were undertaken only sporadically, such as the study of the Silurian rocks of Neuvillesous-Huy (Maes et al., 1978), the study of the brachiopods and trilobites of the Upper Ordovician Fosses Formation (Sheehan, 1987; Lespérance and Sheehan, 1987), the study of the graptolites and acritarchs of the lower Llanvirn of the Huy Formation (Servais and Maletz, 1992) and a general study of the Fosses Formation in the Puagne area (Tourneur et al., 1993). More recently, fieldwork in the Condroz Inlier was reactivated, resulting in several studies of the Ordovician of the Condroz Inlier (De Geest, 1998 ms; Billiaert, 2000 ms, Vanmeirhaeghe, $2001 \mathrm{~ms}$; Vanmeirhaeghe, 2002, ms; Vanmeirhaeghe and Verniers, 2002, 2004). An overview of the litho- and biostratigraphical knowledge of the Condroz Inlier is given in Verniers et al., 2001.

The aim of this paper is to present a detailed lithostratigraphical and chitinozoan biostratigraphical study of the most complete section in the Upper Ordovician Vitrival-Bruyère and Fosses formations of the parautochtonous central part of the Condroz Inlier. This will allow correlation on litho- and biostratigraphical grounds with the allochtonous Puagne Inlier, in the western part of the Condroz Inlier, and permit to see possible facies differences between the two regions. Correlation with other chitinozoan biozonations will allow for the first time accurate dating of the sediments of the study area.

\section{Previous studies on the Vitrival-Bruyère and Fosses formations}

\subsection{The Vitrival-Bruyère Formation}

\subsubsection{Lithostratigraphy}

The Vitrival-Bruyère Formation (sensu Maillieux, 1926) consists of an alternation of dark grey micaceous shales and dark sandstone beds. He introduced the term "Assise de Vitrival-Bruyère" for this unit of "blackish, silky and fine micaceous shale with quartzite intercalations". The stratotype section is located in the river bed of the Ruisseau le Treko, west of the Hamlet of La Bruyère, 500 to $1050 \mathrm{~m}$ east of the church of Vitrival. (Verniers et al., 2001). In the stratotype section, neither the base nor the top of the formation is visible, so the term "formation" should be regarded as informal.

\subsubsection{Chrono- and biostratigraphy}

Graptolites from the stratotype section at VitrivalBruyère were first described by Lassine (1913a), who inferred an Arenig age from these finds. Moreover, he found trilobites (Aeglina binodosa Salter) and Orthoceras sp. in this locality. Elles (in Lassine, 1914a) determined the graptolites as Leptograptus validus Lapworth, from which an upper Llandeilo age was deduced. In a later publication, Lassine (1914b) extended the age to the basal Caradoc. Maillieux $(1926,1933)$ inferred from the presence of the latter and other graptolite species (Dicellograptus exilis Elles \& Wood and Leptograptus latus Elles \& Wood) the most likely presence of the C. peltifer Biozone (now equivalent to the foliaceus Biozone, upper part of "Ordovician Stage 5"). Bulman (1950) restudied the collections of Maillieux and suggested an age near that of the $C$. peltifer Biozone for the graptolite finds from Vitrival-Bruyère. Billiaert (2000, ms) investigated the lithostratigraphy and the chitinozoans of the type section and found several specimens of Laufeldochitina stentor (Eisenack, 1937).

\subsection{The Fosses Formation}

\subsubsection{Lithostratigraphy}

The Vitrival-Bruyère Formation is thought to be unconformably overlain by the Fosses Formation in the study area (Michot, 1934, 1954). As defined by Martin (1969), the Fosses Formation comprises two members:

a) The lower Bois-de Presles Member, comprising thin-bedded muddy limestone and green-grey bioturbated calcareous shale to siltstone with some thin limestone layers. It is rather rich in brachiopods, 
crinoids, trilobites, bryozoans, corals, echinoderm debris, cystoids, molluscs and algae (Tourneur et al., 1993). At some localities, as in the study area, the lower beds of the Fosses Formation contain a matrixsupported conglomerate: black, well rounded shale pebbles in a calcareous shale to silt matrix (Michot, 1954). The limestone cobble conglomerate of Cocriamont (Stainier, 1926; Tourneur et al., 1993), however, formally supposed to be a lateral facies change of the matrix-supported conglomerate at the base of the Fosses Formation, has recently been shown to be situated at a much higher level in the overlying Génicot Formation (Vanmeirhaeghe and Verniers, 2004). It is supposed to be the lithological expression of the sea-level drop caused by the Hirnantian glaciation (Vanmeirhaeghe and Verniers, 2004.).

b) The upper Faulx-les-Tombes Member, often referred to as "schistes mouchetés" (Lassine, 1913b), consisting of green siltstones with dark grey bioturbational elliptic or fusiform spots, interpreted as the ichnofossil Chondrites sp. (Verniers et al., 2001) and containing one known macrofauna level (Michot, 1934). The type section, studied in this paper, is located along the Rue du Bois Grand-Pré (Martin, 1969), from 38 to $228 \mathrm{~m}$ southwest of the crossroad with the Chaussée de Gramptinne (road number N 942; Fig. 2).

In the allochtonous Puagne Inlier, a $2 \mathrm{~m}$ thick heavily bioturbated layer, with its base $4 \mathrm{~m}$ below that of the possibly Hirnantian Génicot Formation and situated in the Bursachitina umbilicata Biozone, is lithologically

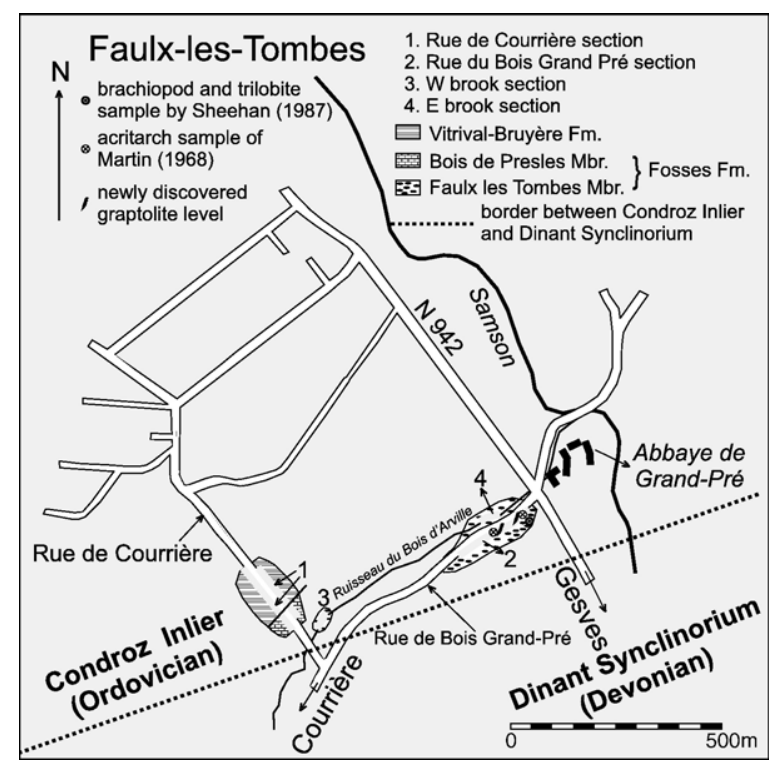

Fig. 2. Detailed location map of the Faulx-les-Tombes area and the studied sections. equivalent to the Faulx-les-Tombes Member (Vanmeirhaeghe and Verniers, 2004).

\subsubsection{Chrono- and biostratigraphy}

On the base of different brachiopod and trilobite finds in the Fosses Formation from the entire Condroz Inlier, Michot (1954) subdivided the formation in different biozones. However, after revising most collections of the Fosses Formation, Sheehan (1987) concluded that this biozonation is invalid and should be abandoned.

The brachiopods and trilobites of the Fosses Formation indicate a pre-Hirnantian Ashgill age (Sheehan, 1987; Lespérance and Sheehan, 1987). Cystoids studied by Regnell (1951) point also to an Ashgill age. Vanmeirhaeghe and Verniers (2004) studied the chitinozoans of the Fosses Formation in the western part of the Condroz Inlier (including the Puagne Inlier) and recognised the presence of the Baltoscandian Tanuchitina bergstroemi and Conochitina rugata chitinozoan biozones by the index species. These two biozones are also identified in the Avalonian type Ashgill area, Cautley District, U.K. (Vandenbroucke et al., 2005). Further, the Spinachitina fossensis and Bursachitina umbilicata (as Bursachitina sp. 1 in Vanmeirhaeghe and Verniers, 2004) Avalonian biozones (defined by Vandenbroucke et al., 2005) were discovered in the upper part of the Bois de Presles Member here (Vanmeirhaeghe and Verniers, 2004). The Baltoscandian Biozones indicate an upper Vormsi to middle Pirgu age for the lowermost sampled to the middle part of the Bois de Presles Member. Correlation with the biozones of the Avalonian type Ashgill area (Vandenbroucke et al., 2005) provided a Cautleyan to Rawtheyan age for the studied part of the Bois de Presles Member.

\section{Location of the study area}

The study area is situated in the central part of the Condroz Inlier on the district of Faulx-les-Tombes (Gesves), $12 \mathrm{~km}$ ESE of Namur (Fig. 1).

Two main outcrops are studied (Fig. 2): the first, the Rue de Courrière section, containing the VitrivalBruyère Formation and the Bois de Presles Member of the Fosses Formation, was studied mostly in the W slope along the Rue de Courrière, from 117.1 to $280.0 \mathrm{~m} \mathrm{NW}$ of the crossroad with de Rue du Bois Grand-Pré. In the E slope, only the part with the contact between the Vitrival-Bruyère and the Fosses Formation was studied over $5 \mathrm{~m}$. The second outcrop, the Rue de Bois GrandPré section, is the type section of the Faulx-les-Tombes Member (see Section 2.2.1. for exact location). 
Additional outcrops, in which the Faulx-les-Tombes Member is present, were studied in and along the river bed of the Ruisseau du Bois d'Arville: the eastern brook section (E brook), from 104 tot $140 \mathrm{~m} \mathrm{SW}$ of the crossroad with the N 942 and the western brook section (W brook), from approximately 30 to $70 \mathrm{~m} \mathrm{NW}$ of the bridge on the Rue de Courrière that crosses the Ruisseau de Bois d'Arville (Fig. 2). The E brook section is correlated with the Rue du Bois Grand-Pré section on geometrical basis.

\section{History of the studied outcrops}

The Rue de Courrière section was first studied by Michot (1934). He described the succession from north to south (stratigraphically from bottom to top), over a total distance of about $70 \mathrm{~m}$ (Fig. 3):

a) Vitrival-Bruyère Formation: blue micaceous, sandy shales, with sometimes thick intercalations of sandstone and black quartzite, visible over a distance of $62 \mathrm{~m}$ and with a minimal thickness of $40 \mathrm{~m}$.

b) The southernmost of these blue shales, dipping $50^{\circ} \mathrm{S}$, are in contact with the Fosses Formation: greywacke layers, dipping $75^{\circ} \mathrm{S}$. At the base of the latter, Michot (1934) described small black pebbles dispersed in sandy shale. According to this author (1934, 1954), the contact between a) and b) is an unconformity. Stratigraphically $4 \mathrm{~m}$ above the contact, a fossil-bearing level was found, containing trilobites and brachiopods and regarded as Caradoc by Michot (1934). Stratigraphic thickness: $6 \mathrm{~m}$.

c) Until the southern end of the outcrop, green sandy shales, sometimes slightly calcareous, associated with 'schistes mouchetés' (Fosses Formation).

Michot (1934) described the 'schistes mouchetés' (Faulx-les-Tombes Member of the Fosses Formation; Martin, 1969) along the whole Rue du Bois Grand-Pré section and estimated the thickness of these rocks to be about $85 \mathrm{~m}$. He found, $40 \mathrm{~m} \mathrm{~W}$ of the crossroad with the Chaussée de Gramptinne (N942), an extremely fossiliferous horizon containing trilobites and brachiopods. Michot (1934) attributed this horizon

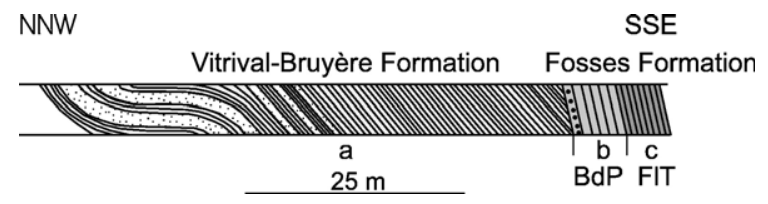

Fig. 3. Cross-section of the eastern slope of the Rue de Courrière section. BdP: Bois de Presles Member; FIT: Faulx-les-Tombes Member. For explanation of a, b, c, see Section 4. Redrawn from Michot (1934). to the Caradoc (sensu lato) in 1934, later revising this attribution to the Ashgill (Michot, 1954). Martin (1969) investigated two acritarch samples from this outcrop $(55 \mathrm{~m}$ and about $120 \mathrm{~m} \mathrm{SW}$ of the crossroad, see Fig. 2) but did not find any microfossils. Lespérance and Sheehan (1987) sampled a level identical to the $55 \mathrm{~m}$ sample of Martin and found a distinct pre-Hirnantian Ashgill brachiopod and trilobite fauna in it.

\section{Lithostratigraphical results (Fig. 4)}

Three lithofacies are distinguished in the studied outcrops.

\subsection{The Vitrival-Bruyère Formation}

The lowermost facies consists of dark grey to black micaceous shale, with intercalations of dark grey micaceous fine sandstone, attributed to the VitrivalBruyère Formation by Michot (1934). Whereas the latter author only saw this formation outcropping over a distance of $62 \mathrm{~m}$ (see above), the Vitrival-Bruyère Formation became visible over a distance of about $137 \mathrm{~m}$ during this study, after cleaning the section profoundly. The stratigraphical thickness of the observable part of the Vitrival-Bruyère Formation is now estimated at about $76 \mathrm{~m}$. In contrast to the type locality (Maillieux, 1926), the sandstone levels are much thinner in the study area (Maximum $\pm 0.25 \mathrm{~m}$, locally $0.39 \mathrm{~m}$ in contrast to the maximum of about $2.50 \mathrm{~m}$ in the type section) but they are more abundant. Few sandstone beds are observed in the lowermost studied part of the section, but their number increases towards the top of the Vitrival-Bruyère Formation. As will be shown further with chitinozoan evidence, the part of the Vitrival-Bruyère Formation outcropping here is younger than the part present in the type section.

Detailed observation in the Rue de Courrière section allowed for the first time the recognition of six matrixsupported conglomerate beds in the Vitrival-Bruyère Formation (Fig. 4). Their thickness is often difficult to estimate due to faulting and the unclear or absent stratification of the beds, but is nevertheless not negligible (possibly more than $15 \mathrm{~m}$ for the lower bed, estimated by calculating the thickness using the same strike as the under- and overlying strata). A tentative interpretation points to debris-flow deposits, but further research is needed to confirm this. Towards the top of the Vitrival-Bruyère Formation, several thin microconglomeratic levels were also observed. 


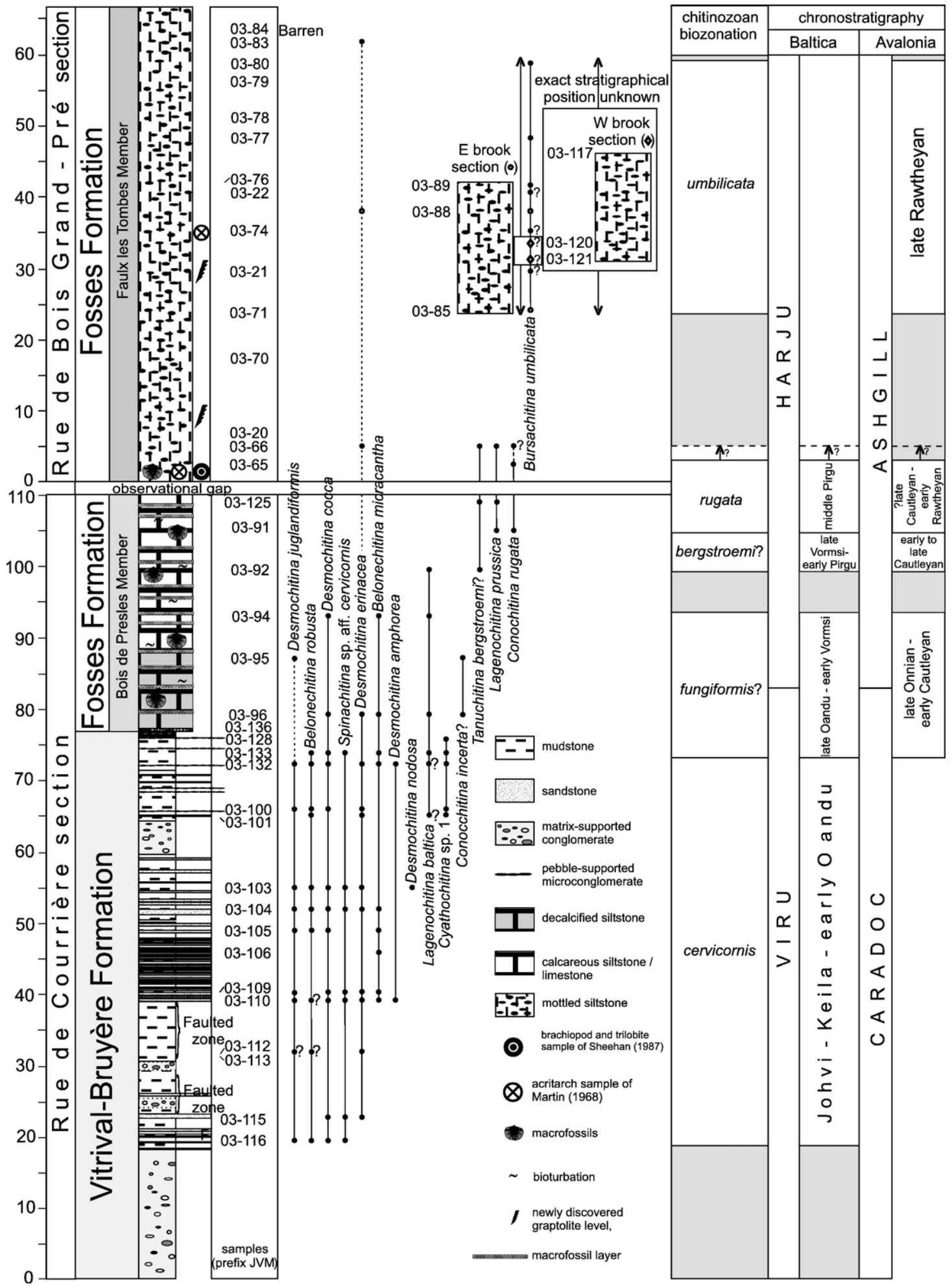

Fig. 4. Lithostratigraphical log and range chart of selected chitinozoan species of the Rue de Courrière and the Rue du Bois Grand Pré sections. On the right, correlation with the Baltoscandian (Nõlvak and Grahn, 1993) and the Avalonian (Vandenbroucke et al., 2005) biozonations. 


\subsection{The Fosses Formation}

\subsubsection{The Bois de Presles member}

The second facies is a bioturbated, fossiliferous, calcareous or decalcified, green-grey siltstone, described as the Fosses Formation by Michot (1934) and assigned to the Bois de Presles Member in this study. Dark grey bioturbation traces occur in this facies, described by Michot (1934) as "associated mottled mudstone". Most macrofossils are concentrated in layers; in between these layers, macrofossils only occur in limited numbers. The Bois de Presles Member was observed over a distance of $35.6 \mathrm{~m}$ in outcrop and has a stratigraphical thickness of circa $33.5 \mathrm{~m}$. The lowermost $10 \mathrm{~m}$ of the Bois de Presles Member is decalcified, whereas carbonates are present in the younger strata of this member.
The contact with the Vitrival-Bruyère Formation is complicated by faults, but at both sides of the contact, dark grey well-rounded pebbles occur in a matrix. Michot (1934) only observed this kind of lithology at the base of the Fosses Formation and deduced from this observation an unconformity overlain by a basal conglomerate (see also Section 4). This interpretation is not confirmed by our observations and more study is necessary to clarify the nature of the contact.

\subsubsection{The Faulx-les-Tombes member}

The third facies contains green-grey micaceous siltstone, with dark grey fusiform to elliptic bioturbation traces, oriented parallel to the bedding. This facies only crops out along the Rue de Bois Grand-Pré section and in $\mathrm{E}$ and $\mathrm{W}$ brook sections. It is known as the Faulx-lesTombes Member (Martin, 1969). Except for a macro-

Table 1

Chitinozoan abundance in the samples of the Rue de Courrière section (number of specimens)

\begin{tabular}{|c|c|c|c|c|c|c|c|c|c|c|c|c|c|c|c|c|c|c|c|c|c|c|c|c|c|c|c|c|c|c|c|c|c|}
\hline 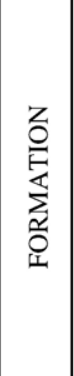 & 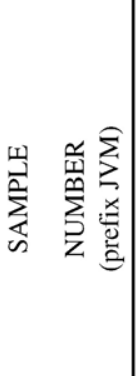 & 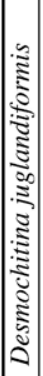 & 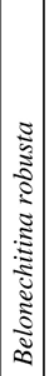 & 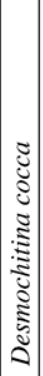 & 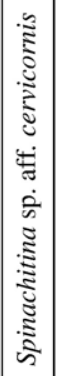 & 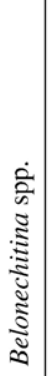 & 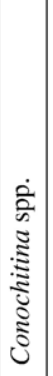 & 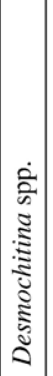 & 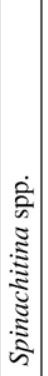 & 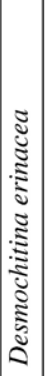 & 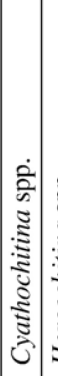 & 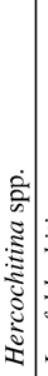 & 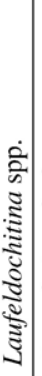 & 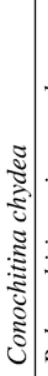 & 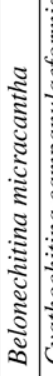 & 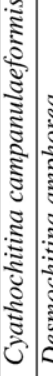 & 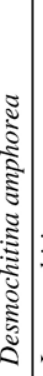 & 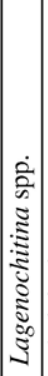 & 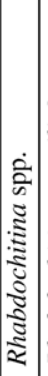 & 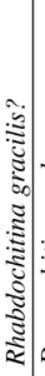 & 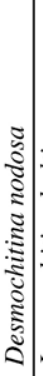 & 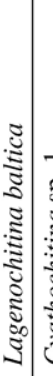 & 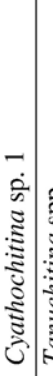 & 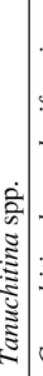 & 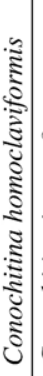 & 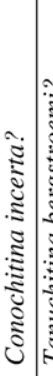 & 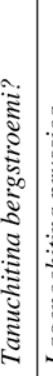 & 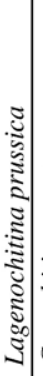 & 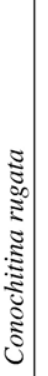 & 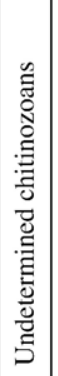 & 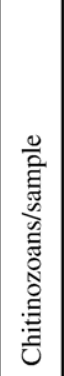 & 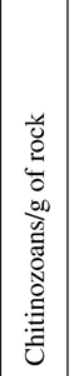 & 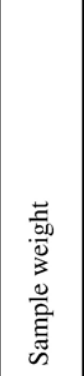 \\
\hline \multirow{7}{*}{ 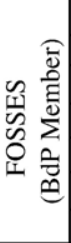 } & 03-125 & & & & & 7 & 17 & 1 & & & 3 & & & & & & & 4 & & & & & & & & & 1 & 1 & & 70 & 104 & \begin{tabular}{|l|}
5.78 \\
\end{tabular} & 18.00 \\
\hline & 03-091 & & & & & 5 & 7 & 4 & & & 5 & & & & & & & 4 & & & & & & & & & & 2 & 11 & 32 & 70 & 3.64 & 19.24 \\
\hline & 03-092 & & & & & & & & & & 1 & & & & & & & 2 & & & & 3 & & & & & 19 & & & 11 & 36 & 1.96 & 18.39 \\
\hline & 03-094 & & & 2 & & 12 & 5 & \begin{tabular}{|l|}
7 \\
\end{tabular} & 3 & & 6 & & & & 1 & & & 16 & & & & 4 & & & & & & & & 33 & 89 & \begin{tabular}{|l|}
4.80 \\
\end{tabular} & \begin{tabular}{|l|}
18.56 \\
\end{tabular} \\
\hline & 03-095 & 1 & & & & & 1 & 1 & & & 1 & & & & & & & & & & & & & & & 2 & & & & 24 & 30 & \begin{tabular}{|l|}
1.64 \\
\end{tabular} & 18.27 \\
\hline & 03-096 & & 1 & 1 & & 12 & 6 & 5 & 1 & 2 & 5 & & & & 1 & & & 16 & & & & 6 & & & & 4 & & & & 58 & 118 & \begin{tabular}{|l|}
6.69 \\
\end{tabular} & 17.65 \\
\hline & 03-136 & & & & & & & & & & & & & & & & & & & & & & & & & & & & & & 0 & \begin{tabular}{|l|}
0.00 \\
\end{tabular} & 17.80 \\
\hline \multirow{17}{*}{ 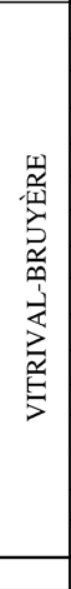 } & 03-128 & & & & & & 1 & & & & 14 & & & & & & & 2 & & & & & 29 & & & & & & & 11 & 57 & \begin{tabular}{|l|}
3.20 \\
\end{tabular} & \begin{tabular}{|l|}
17.81 \\
\end{tabular} \\
\hline & 03-133 & & \begin{tabular}{|l|}
2 \\
\end{tabular} & \begin{tabular}{|l|}
1 \\
\end{tabular} & 6 & 9 & 9 & \begin{tabular}{|l|}
3 \\
\end{tabular} & 4 & & & 1 & 2 & & \begin{tabular}{l|l}
4 & \\
\end{tabular} & 1 & & 4 & & & & \begin{tabular}{l|l}
2 & 3 \\
\end{tabular} & 3 & & 2 & & & & & 25 & 78 & \begin{tabular}{|l|}
4.27 \\
\end{tabular} & 18.26 \\
\hline & 03-099 & & & & & & & & & & & & & & & & & & & & & & & & & & & & & & 0 & 0.00 & \begin{tabular}{|l|}
18.44 \\
\end{tabular} \\
\hline & 03-132 & 1 & \begin{tabular}{|l|}
3 \\
\end{tabular} & 6 & & 29 & 31 & \begin{tabular}{|l|}
14 \\
\end{tabular} & 1 & \begin{tabular}{|l|}
1 \\
\end{tabular} & \begin{tabular}{|l|l}
11 & 1 \\
\end{tabular} & 2 & 1 & & \begin{tabular}{|l|}
3 \\
\end{tabular} & \begin{tabular}{|l|l}
1 & \\
\end{tabular} & 1 & 6 & \begin{tabular}{|l|l}
2 \\
\end{tabular} & 1 & & \begin{tabular}{l|l}
$2 ?$ & 1 \\
\end{tabular} & \begin{tabular}{l|l}
1 & \\
\end{tabular} & 4 & & & & & & 103 & 224 & 12.50 & 17.92 \\
\hline & $03-100$ & 4 & 1 & 4 & & 9 & 14 & 4 & 2 & \begin{tabular}{|l|}
1 \\
\end{tabular} & \begin{tabular}{|l|l}
2 & \\
\end{tabular} & 2 & 1 & & & & & 1 & & & & & 3 & & & & & & & 28 & 76 & \begin{tabular}{|l|}
4.09 \\
\end{tabular} & 18.56 \\
\hline & 03-101 & & 4 & & & 11 & 6 & 1 & & \begin{tabular}{|l|}
1 \\
\end{tabular} & 9 & & & 4 & & & & & & & & \begin{tabular}{l|l}
$4 ?$ & 5 \\
\end{tabular} & 5 & & & & & & & 17 & 62 & \begin{tabular}{|l|}
3.32 \\
\end{tabular} & \begin{tabular}{|l|}
18.66 \\
\end{tabular} \\
\hline & 03-103 & 2 & 28 & 12 & 4 & 16 & 14 & 8 & 1 & 9 & \begin{tabular}{|l|l}
4 & \\
\end{tabular} & 1 & & 2 & 2 & & & & & & 1 & & & & & & & & & 80 & 184 & 10.27 & 17.92 \\
\hline & 03-104 & 2 & 7 & 5 & 22 & 17 & 24 & \begin{tabular}{|l|}
7 \\
\end{tabular} & & 2 & \begin{tabular}{|l|l|}
7 \\
\end{tabular} & 1 & & 1 & \begin{tabular}{|l|l|}
3 \\
\end{tabular} & 1 & & 1 & 4 & & & & & & & & & & & 25 & 129 & \begin{tabular}{|l|}
7.10 \\
\end{tabular} & 18.18 \\
\hline & 03-105 & 2 & 10 & 1 & & 1 & 6 & 3 & & & & & & & 1 & & & & & & & & & & & & & & & 7 & 33 & 1.85 & \begin{tabular}{|l|}
17.84 \\
\end{tabular} \\
\hline & 03-106 & & & & & & & & & & & & & & & & & & & & & & & & & & & & & & 0 & \begin{tabular}{|l|}
0.00 \\
\end{tabular} & \begin{tabular}{|l|}
18.88 \\
\end{tabular} \\
\hline & 03-109 & 7 & & \begin{tabular}{|l|}
9 \\
\end{tabular} & \begin{tabular}{|l|}
57 \\
\end{tabular} & 41 & 75 & \begin{tabular}{|l|}
13 \\
\end{tabular} & & 10 & \begin{tabular}{|l|}
12 \\
\end{tabular} & 1 & 1 & 2 & 6 & & & 7 & & 5 & & & & & & & & & & 48 & 294 & 16.51 & 17.81 \\
\hline & $03-110$ & 3 & $3 ?$ & 14 & 23 & 28 & \begin{tabular}{|l|}
37 \\
\end{tabular} & \begin{tabular}{|l|l|}
16 \\
\end{tabular} & 13 & \begin{tabular}{|l|}
5 \\
\end{tabular} & \begin{tabular}{|l|l|}
5 & \\
\end{tabular} & 1 & & 14 & \begin{tabular}{|l|l|}
10 \\
\end{tabular} & \begin{tabular}{|l|l}
6 & 2 \\
\end{tabular} & 2 & \begin{tabular}{|l|}
6 \\
\end{tabular} & 7 & & & & & & & & & & & 144 & \begin{tabular}{|l|}
337 \\
\end{tabular} & 18.22 & \begin{tabular}{|l|}
18.50 \\
\end{tabular} \\
\hline & 03-112 & $1 ?$ & $1 ?$ & & & & 1 & 1 & & 1 & & & & & & & & & & & & & & & & & & & & 12 & 17 & \begin{tabular}{|l|l|}
0.90 \\
\end{tabular} & 18.84 \\
\hline & 03-113 & & & & & & & & & & & & & & & & & & & & & & & & & & & & & & 0 & \begin{tabular}{|l|}
0.00 \\
\end{tabular} & 17.05 \\
\hline & 03-115 & & & 1 & \begin{tabular}{|l|}
18 \\
\end{tabular} & 2 & 4 & 1 & 2 & 2 & & 1 & 1 & & & & & & & & & & & & & & & & & 11 & 43 & 2.28 & \begin{tabular}{|l|}
18.86 \\
\end{tabular} \\
\hline & 03-116 & 13 & \begin{tabular}{|l|l|}
5 \\
\end{tabular} & \begin{tabular}{|l|}
3 \\
\end{tabular} & 5 & 18 & 12 & \begin{tabular}{|l|l|}
11 \\
\end{tabular} & 3 & & & & & & & & & & & & & & & & & & & & & 41 & \begin{tabular}{|l|}
111 \\
\end{tabular} & 6.16 & 18.01 \\
\hline & Total & 35 & 65 & 59 & 135 & 217 & 270 & 100 & 30 & 34 & \begin{tabular}{|l|l|}
85 & 1 \\
\end{tabular} & 10 & 6 & 23 & \begin{tabular}{l|l}
31 \\
\end{tabular} & \begin{tabular}{l|l}
9 & 3 \\
\end{tabular} & \begin{tabular}{l|l}
3 \\
\end{tabular} & 68 & \begin{tabular}{|l|l|}
13 \\
\end{tabular} & 6 & 1 & \begin{tabular}{l|l}
16 & 4 \\
\end{tabular} & \begin{tabular}{l|l}
41 & \\
\end{tabular} & 4 & 2 & \begin{tabular}{l|l}
6 & 2 \\
\end{tabular} & \begin{tabular}{l|l}
20 & 8 \\
\end{tabular} & \begin{tabular}{l|l}
8 & \\
\end{tabular} & $\begin{array}{ll}11 & 7 \\
\end{array}$ & 781 & 2092 & \begin{tabular}{|l|}
4.99 \\
\end{tabular} & 419.45 \\
\hline
\end{tabular}

Sample weight and chitinozoan abundance/gram of rock are indicated on the right; barren samples are indicated in grey. 
fossil level at the lowermost observed part of the member (Michot, 1934; Sheehan, 1987) and two graptolite finds (own observations), this section is devoid of any macrofossils. The contact with neither the Bois de Presles Member nor the top of this member was observed. The stratigraphical thickness of this member is estimated by our measurements at $\pm 66 \mathrm{~m}$ (opposed to Michot's, 1934 estimate of circa $80 \mathrm{~m}$ ).

\section{Sampling, fieldwork and sample processing}

Chitinozoans were studied from 45 samples (see Tables 1 and 2), of which 16 samples are taken from the Vitrival-Bruyère Formation, 7 from the Bois de Presles Member and 22 from the Faulx-les-Tombes Member. Four samples appeared to be barren. From the 41 productive samples, a total of 2898 chitinozoans was studied. The chitinozoans are poorly to moderately well preserved and the assemblages are fairly diverse. From the studied sections, the Vitrival-Bruyère Formation bears the richest chitinozoan samples (up to 18.22 chitinozoans $/ \mathrm{g}$ rock). The mean number of chitinozoans decreases upward (6.97 chitinozoans/g rock for the Vitrival-Bruyère Formation; 4.08 chitinozoans/g rock for the Bois de Presles Member; 2.21 chitinozoans/g rock for the Faulxles-Tombes Member). The chitinozoans were extracted from the samples using standard palynological techniques (Paris, 1981) and than handpicked and mounted on slides for SEM (JEOL 6400) study.

\section{Chitinozoan results (Tables 1 and 2, Plates I and II)}

The lowermost sampled part of the Vitrival-Bruyère Formation contains as most important species Desmochitina juglandiformis Laufeld, 1967 and Spinachitina sp. aff. cervicornis (Eisenack, 1931). Both species range trough almost the entire sampled part of the formation.

Table 2

Chitinozoan abundance in the Rue de Bois Grand-Pré section (number of specimens)

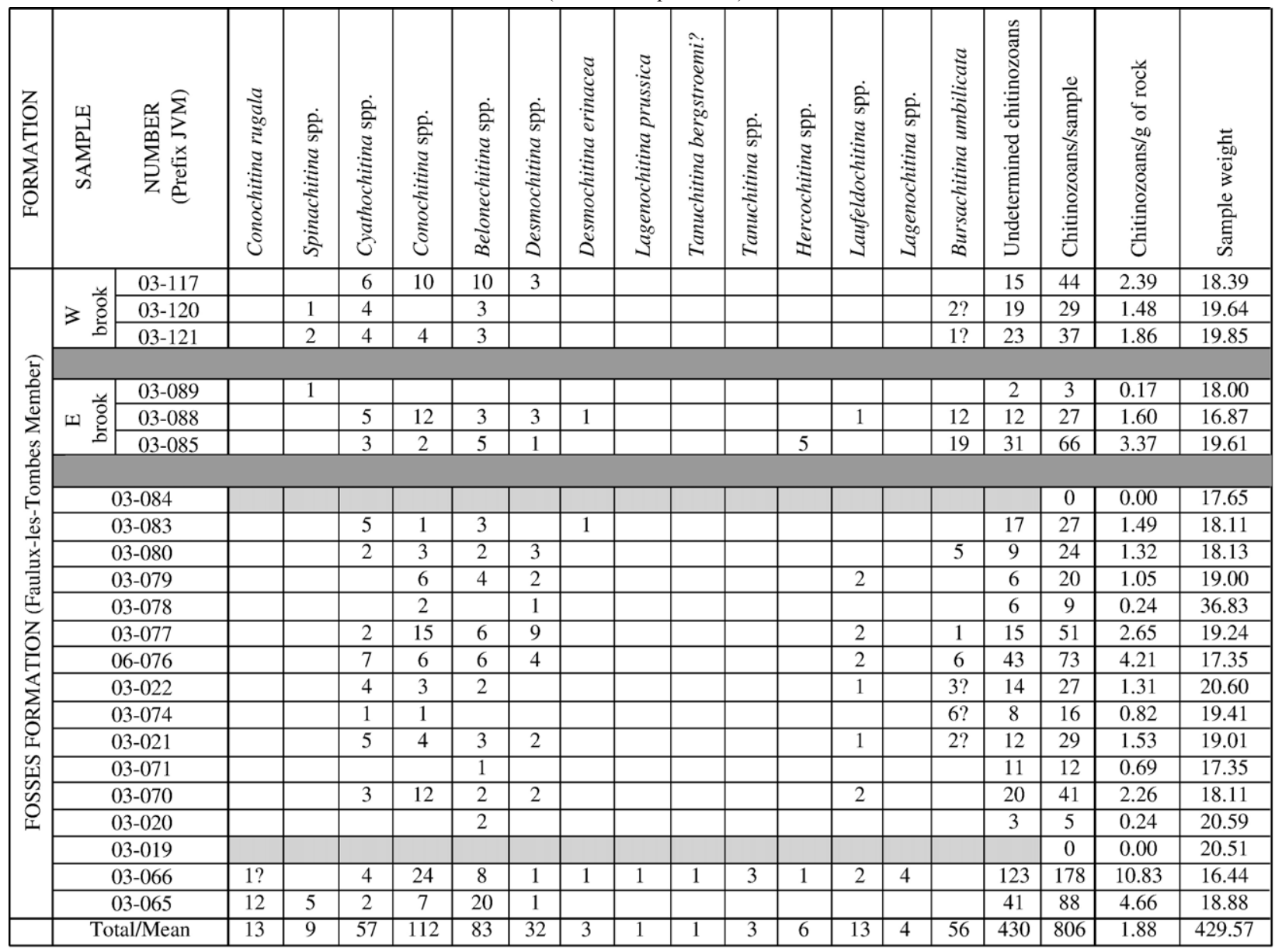

Sample weight and chitinozoan abundance/gram of rock are indicated on the right; barren samples are indicated in grey. 
Other characteristic chitinozoans from the VitrivalBruyère Formation are Belonechitina robusta (Eisenack, 1959), Desmochitina cocca Eisenack, 1931 and Desmochitina erinacea (Eisenack, 1931). Throughout the formation, many specimens of Belonechitina spp., of which some are assigned to Belonechitina micracantha Eisenack, 1931), occur. However, a determination to species level is difficult due to the rather poor state of preservation of the vesicles. Other constituents of the chitinozoan assemblage in this part of the VitrivalBruyère Formation are Conochitina spp., Cyathochitina spp., Hercochitina spp., Desmochitina spp. Lagenochitina spp., and Laufeldochitina spp., determined to generic level for the same reason as described above.

In the higher part of the Vitrival-Bruyère Formation, in JVM 03-101, specimens probably belonging to Lagenochitina baltica Eisenack, 1931 occur. The first well-preserved specimens of this species occur somewhat higher, in JVM 03-133. Cyathochitina sp. 1 also has its first occurrence in JVM 03-101, but only ranges to the top of the Vitrival-Bruyère Formation, where it is found to be abundant in a relatively "oligospecific" assemblage (in JVM 03-128).

The transition to the Fosses Formation does not really correspond with the occurrence of new species, as might be expected in the case of an unconformity. Perhaps it is noteworthy that Conochitina incerta? Eisenack, 1962 has its first occurrence in the lowermost productive sample of this formation. Tanuchitina bergstroemi? Laufeld, 1967 occurs somewhat higher (JVM 03-092) but is only present as broken specimens. Conochitina rugata Nõlvak, nomen nudum is recovered higher from JVM 03-091, $5 \mathrm{~m}$ above JVM 03-092. At the same level, specimens belonging to L. prussica Eisenack, 1931 occur for the first time. The assemblage of the Bois de Presles Member is completed by many Belonechitina spp., Conochitina spp., Cyathochitina spp., Desmochitina spp. and Lagenochitina spp.

In the lowermost sample of the Faulx-les-Tombes Member, JVM 03-065, Conochitina rugata Nõlvak, nomen nudum also occurs. From JVM 03-066, slightly higher than JVM 03-065, equivocal C. rugata Nõlvak, nomen nudum, T. bergstroemi? Laufeld, 1967 and $L$. prussica Eisenack, 1931 are recovered (one specimen of each). It is only at a level, estimated at a stratigraphic position of less than $20 \mathrm{~m}$ higher than JVM 03-066 that the next indicative species occurs: Bursachitina umbilicata Vandenbroucke et al., 2005 (sample JVM 03-085, E brook section). It is also recognised from samples in the Rue du Bois Grand-Pré section and probably also in the $\mathrm{W}$ brook section. The exact stratigraphical position of the latter section is, however, not known, due to its isolated location between the Rue de Courrière and Rue du Bois Grand-Pré sections (see Fig. 2). Throughout the Faulx-les-Tombes Member, the assemblages are characterised by the presence of Cyathochitina spp., Conochitina spp., Belonechitina spp., Desmochitina spp. and Laufeldochitina spp., with specimens determinable to generic level only because of the poor preservation state.

Plate I. Chitinozoans from the Vitrival-Bruyère and the Fosses Formation. All dimensions are in microns.

1. Bursachitina umbilicata. JVM 03-85, Fosses Formation, Faulx-les-Tombes Member. L: 90; Dp: 65; Dc: 55.

Bursachitina umbilicata. Same specimen as 1, tilted. Detail of apertural pole. The operculum is still in place. Tanuchitina bergstroemi?. Same specimen as 3. 


\section{ARTICLE IN PRESS}

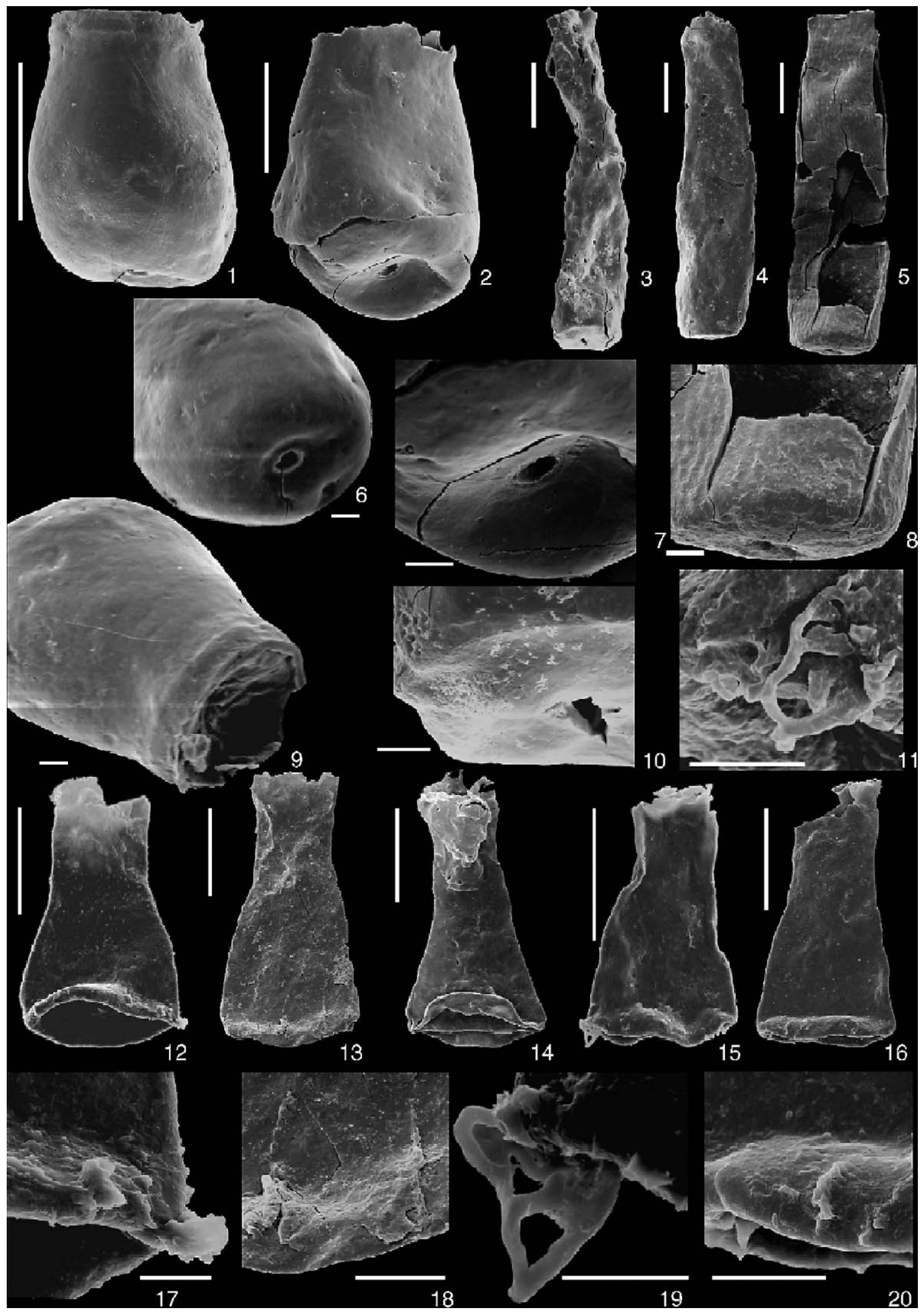




\section{Systematic palaeontology section}

In the following, dimensions are given in $\mu \mathrm{m}$. For the dimensions, abbreviations are used following Paris (1981). $L=$ total length; $\mathrm{Db}=$ diameter at the base; $\mathrm{Dp}=$ chamber diameter; $\mathrm{Dc}=$ diameter of the oral tube. The mean values are given between parentheses.

Order Prosomatifera Eisenack, 1972

Family Conochitininae Paris, 1981

Subfamily Spinachitininae Paris, 1981

Genus Spinachitina Schallreuter, 1963 emend. Paris et al., 1999

Spinachitina sp. aff. cervicornis (Eisenack, 1931)

Material: 135 specimens from JVM 03-116 to JVM 03133, Vitrival-Bruyère Formation.

Dimensions: (based on 135 specimens) L: 110-150 (129); Dp: 55-90 (69); Dc: 30-60 (40); maximal spine length: 20.

Description: Spinachitina species with a cylindroconical vesicle and an inconspicuous flexure, separating the conical chamber and the cylindrical neck. The neck comprises one third to half of the total length. The vesicle wall is smooth to granular, the granulation becoming more pronounced towards the base. The chamber base is flat. The subrounded basal margin is surrounded with a crown of multi-rooted to thick-based spines, which can have a granular ornamentation. The gently flaring aperture is fringed.

Discussion: the specimens described herein are shorter than Spinachitina cervicornis (Eisenack, 1931), of which the holotype is $240 \mu \mathrm{m}$ long. The proposed neotype (Paris et al., 1999), however, has a length of $140 \mu \mathrm{m}$. The spines of our specimens differ from those of $S$. cervicornis
(Eisenack, 1931): the latter species always has simple spines, whereas our specimens' spines are sometimes multi-rooted and can have a granular ornamentation. Another difference with S. cervicornis (Eisenack, 1931) is the lack of a constriction of the vesicle just above the basal margin. This may be due by the flattening of the specimens, but this cannot explain the total lack of it on all specimens. This species differs from Spinachitina bulmani (Jansonius, 1964) in having larger based spines, which can be more than birooted. However, the shape of the vesicle reminds that of $S$. bulmani.

Subfamily Cyathochitininae Paris, 1981

Genus Cyathochitina Eisenack, 1955 emend. Paris et al., 1999

\section{Cyathochitina sp. 1}

Material: 41 specimens from JVM 03-101 to JVM 03128 , top of the Vitrival-Bruyère Formation

Dimensions: (based on 9 specimens) $L$ : more than 250 (neck broken); Dp: 83-160 (119); Db: 60-110 (99); Dc: 45-75 (65)

Diagnosis: thick-walled Cyathochitina species with an elongated vesicle, an inconspicuous flexure and the greatest width in the lower half of the chamber. The difference between the basal and the greatest width is accentuated by flattening. The vesicle is divided into a chamber and neck by a weak flexure. Due to the poor state of preservation of the material, a complete carina was not observed.

Discussion: the shape of this species most resembles Cyathochitina jenkinsi Neville, 1974. However, the wall of the latter is thinner. The poor state of preservation of the material inhibits further discussion, as no complete specimens were observed.

Plate II. Chitinozoans from the Vitrival-Bruyère and the Fosses Formation. All dimensions are in microns.

Desmochitina cocca. JVM 03-116, Vitrival-Bruyère Formation. L: 85; Dp: 75.

Desmochitina nodosa. JVM 03-103, Vitrival-Bruyère Formation. L: 75; Dp: 63

Desmochitina juglandiformis. JVM 03-109, Vitrival-Bruyère Formation. L: 100; Dp: 75.

Desmochitina juglandiformis. JVM 03-109, Vitrival-Bruyère Formation. L: 100; Dp: 75.

Desmochitina erinacea. JVM 03-104, Vitrival-Bruyère Formation. L: 75; Dp: 65.

Desmochitina amphorea. JVM 03-110, Vitrival-Bruyère Formation. $L: 110$; Dp: 80.

Desmochitina juglandiformis. JVM 03-116, Vitrival-Bruyère Formation. L: 160 (for two specimens); Dp: 75.

Cyathochitina campanulaeformis. JVM 03-110, Vitrival-Bruyère Formation. L: 95; Dp: 98; Dc: 42.

Cyathochitina sp. 1. JVM 03-128, Vitrival-Bruyère Formation. L: 230; Dp: 130, Dc: 75.

Belonechitina micracantha. JVM 03-110, Vitrival-Bruyère Formation. L: 140; Dp: 70; Dc: 40.

Belonechitina robusta. JVM 03-104, Vitrival-Bruyère Formation. L: 210; Dp: 100; Dc: 70.

Belonechitina robusta. JVM 03-104. Same specimen as 11. Detail of the multipode spines.

Conochitina incerta? Same specimen as 14. Detail of the base.

Conochitina incerta? JVM 03-096, Fosses Formation, Bois de Presles Member. L: 90; Dp: 75.

Lagenochitina prussica. JVM 03-091, Fosses Formation, Bois de Presles Member. L: 160; Dp: 115; Dc: 45.

Lagenochitina baltica. JVM 03-092, Fosses Formation, Bois de Presles Member. L: 120; Dp: 120; Dc: 55.

Lagenochitina prussica. Same specimen as 15. Detail of the ornamentation. 


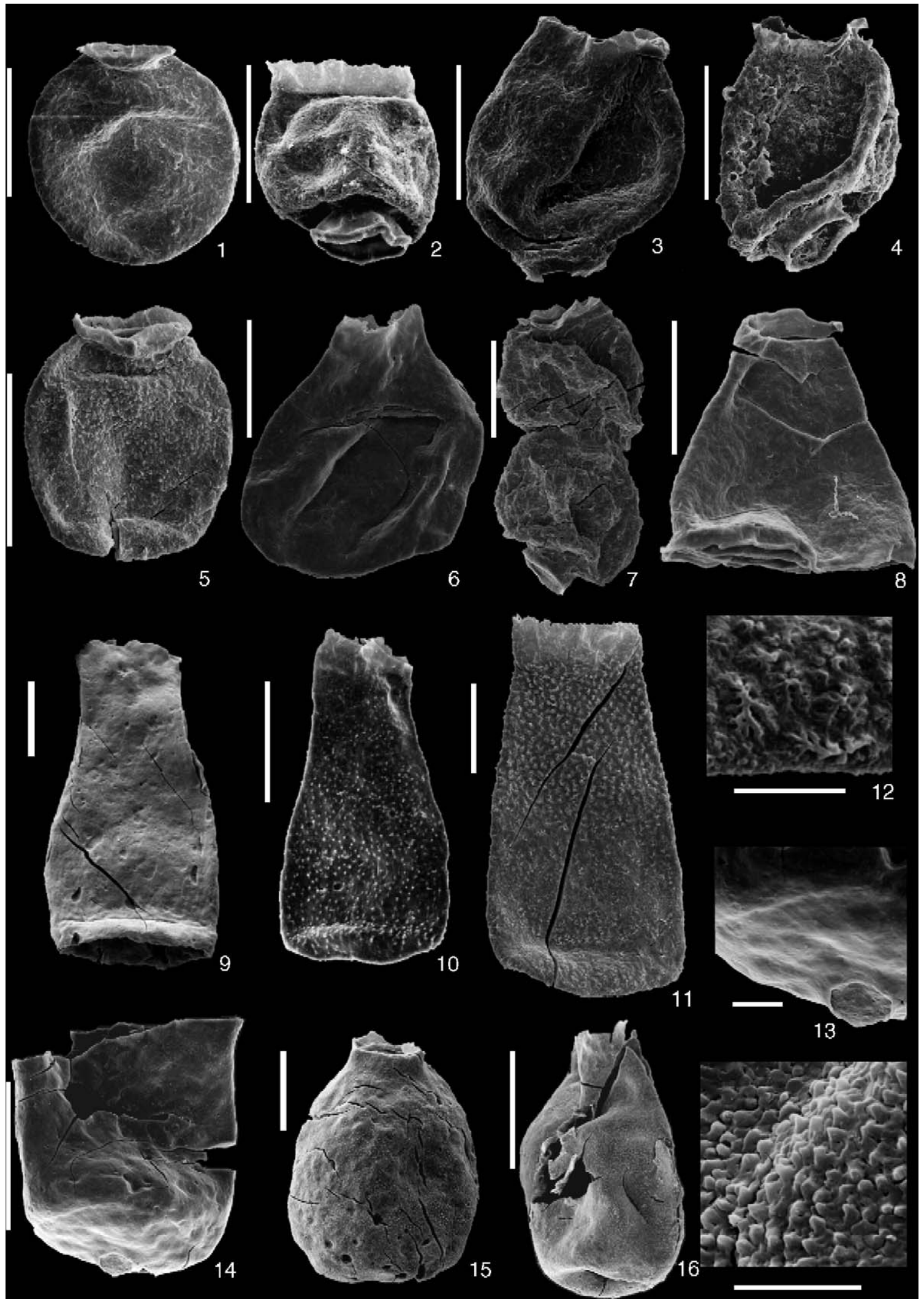




\section{Biozonation}

The Baltoscandian Spinachitina cervicornis Biozone, defined by the total range of the index species by Nõlvak and Grahn (1993), is recognised by the presence of Desmochitina juglandiformis. The range of the latter species coincides with the major part of the cervicornis Biozone in Baltoscandia (Nõlvak and Grahn, 1993). Moreover, Spinachitina sp. aff. cervicornis (Eisenack, 1931) (see below in the systematical part for the description) occurs in about the same stratigraphical interval as D. juglandiformis Laufeld, 1967 in the studied section (see Table 1). Characteristic co-occurring species of the cervicornis Biozone in Baltoscandia, such as Belonechitina robusta (Eisenack, 1959), Desmochitina nodosa Eisenack, 1931 and specimens from the Belonechitina micracantha group were also found in this study. However, Spinachitina multiradiata (Eisenack, 1959), known to co-occur with S. cervicornis in Baltoscandia was not recovered. Also, the Baltoscandian Angochitina multiplex Subbiozone is not present in the study area.

Based on the presence of Desmochitina juglandiformis Laufeld, 1967, the cervicornis Biozone is present in the Vitrival-Bruyère Formation from JVM 03-116 to JVM 03-132. It might extend even somewhat higher, as one single vesicle of $D$. juglandiformis Laufeld, 1967 is recovered from JVM 03-095, from the basal part of the Fosses Formation. However, the limited number of vesicles (only one), the importance of the interval without $D$. juglandiformis Laufeld, 1967 between JVM 03-132 and JVM 03-095, the occurrence of Lagenochitina baltica Eisenack, 1931 (see below) and the presence of reworked material (the matrix-supported conglomerates) in the top of the Vitrival-Bruyère and the base of the Fosses Formation, does not favour this possibility.

Desmochitina juglandiformis Laufeld, 1967 is also found in northern Gondwana (only in southern Spain) in the $B$. robusta Biozone. In the GSSP candidate section for the base of "Ordovician Stage 6" in Hartfell Score, Scotland (Laurentia), D. juglandiformis Laufeld, 1967 was recovered from the upper part of the wilsoni Biozone to the lower part of the clingani Biozone (Verschaeve, 2004, ms; Zalasiewicz et al., 2004).

The Baltoscandian Fungochitina fungiformis Biozone, a total range zone, is possibly recognised in this study by the presence of Lagenochitina baltica Eisenack, 1931 and Conochitina incerta? Eisenack, 1962. As such, this biozone is present from JVM 03-133 to JVM 03-094, including the boundary between the VTB and the Fosses Formation. Fragments with the characteristic ornamentation of L. baltica Eisenack, 1931 are present in the upper part of the VitrivalBruyère (JVM 03-101 and JVM 03-132), but are equivocal, due to this fragmentary nature. Also, the presence of Desmochitina juglandiformis Laufeld, 1967 in JVM 03-100 and JVM 03-132 (above JVM 03-101) does not favour a determination of these fragments as $L$. baltica Eisenack, 1931, as in Baltoscandia these two species do not co-occur (Nõlvak and Grahn, 1993).

The Baltoscandian Cyathochitina angusta and Armoricochitina reticulifera Subbiozones are not recognised by their index fossil, but the presence of the former could be inferred by the occurrence of the Conochitina incerta? Eisenack, 1962 (in Baltoscandia associated with C. angusta Nõlvak and Grahn, 1993) at the base of the Fosses Formation (JVM 03-96 and JVM 03-95). However, the poor preservation state inhibits a convincing determination.

The Baltoscandian Tanuchitina bergstroemi Biozone, a total range zone (Nõlvak and Grahn, 1993) might be present, but the specimens are questionably identified due to the poor preservation state of the material. If one assumes true $T$. bergstroemi Laufeld, 1967 are present, than one must constrain the $T$. bergstroemi Biozone to the partial range of this species in this study, as its top is defined by the first occurrence of Conochitina rugata Nõlvak, nomen nudum, the index fossil of the overlying biozone. This is also the case in the Cautley District, type Ashgill Area, U.K., as shown by Vandenbroucke et al. (2005). Lagenochitina baltica Eisenack, 1931, typically associated with $T$. bergstroemi Laufeld, 1967 in Baltica (Nõlvak and Grahn, 1993), is also recognised herein. The Baltoscandian Acanthochitina barbata Subbiozone has not been found in this study.

The Conochitina rugata Biozone corresponds in Baltoscandia to the total range of the index fossil (Nõlvak and Grahn, 1993) and occurs in this study from the upper (known) part of the Bois de Presles Member (JVM 03-091) to the lower (known) part of the Faulxles-Tombes Member (JVM 03-065 and ?JVM 03-066). It spans the gap between the uppermost sampled Bois de Presles and the lowermost Faulx-les-Tombes members in our study area and indicates the relatively limited importance of this gap, as C. rugata Nõlvak, nomen nudum is a short ranging species.

The Bursachitina umbilicata Biozone, a total range zone, is defined in Avalonia in the type Ashgill area, U. $\mathrm{K}$., by Vandenbroucke et al. (2005). In this study, it is present in the Faulx-les-Tombes Member from JVM 0385 to JVM 03-080. Samples from the W brook section also bear this species, but, as mentioned before, the 
position of this section in relation to the Rue du Bois Grand-Pré is not exactly known.

In the type Ashgill area, U.K., two levels containing Ancyrochitina merga Jenkins, 1970 were observed within the umbilicata Biozone (Vandenbroucke et al., 2005). This is not the case in the present study. Also, the underlying recently defined Spinachitina fossensis Biozone present in the type Ashgill area, U.K. (Vandenbroucke et al., 2005) was not recognised herein. In the type Ashgill area, Bursachitina umbilicata Vandenboucke et al., 2005 and S. fossensis Vanmeirhaeghe and Verniers, 2004 have more or less the same range, but are never found to occur together. As hypothesised by Vandenbroucke et al. (2005), the absence of S. fossensis Vanmeirhaeghe and Verniers, 2004 might be palaeoecologically controlled.

\section{Age assignment (Fig. 4)}

Correlation with the Baltoscandian biozonation (Nõlvak and Grahn, 1993) can be done by means of maximum four biozones, of which the second and the third are only probably present (the cervicornis, fungiformis (?), bergstroemi (?) and rugata Biozones). Correlation with the biozonation of the Avalonian type Ashgill area and Pus Gill type section (Vandenbroucke et al., 2005) is clear by the recognition of maximum four biozones, of which the two first are only probably present (the fungiformis (?), bergstroemi (?), rugata and umbilicata Biozones. Correlations with Laurentia and northern Gondwana can only be done by the presence of Desmochitina juglandiformis Laufeld, 1967.

The part of the Vitrival Bruyère Formation in the Rue de Courrière section, assigned to the cervicornis Biozone (up to JVM 03-132), can be dated as late Idavere to early Oandu (late "Ordovician Stage 5" to early "Ordovician Stage 6") by correlation with the Baltoscandian biozonation. It is rather probable that the part of the cervicornis Biozone, present in the Rue de Courrière section, represents the upper part of the zone, as no Angochitina multiplex (Schallreuter, 1963) (index species for the basal Keila Baltoscandian Subbiozone in the middle part of the cervicornis Biozone, Nõlvak and Grahn, 1993) were found and as we see the first occurrence of Lagenochitina baltica Eisenack, 1931, present in the overlying fungiformis Biozone, in JVM 03-133, a few m above JVM 03-132. No hiatus or major erosive surface was observed between these two samples. This argues for an age assignment to the Keila (except for the basal part)-early Oandu (both early "Ordovician Stage 6") for the studied part of the Vitrival-Bruyère Formation.
Correlation with Laurentia corroborates this age assignment. In the GSSP candidate section for the base of "Ordovician Stage 6" in Hartfell Score, Scotland (Laurentia), Desmochitina juglandiformis Laufeld, 1967 was recovered from the upper part of the wilsoni Biozone to the lower part of the clingani Biozone (upper "Ordovician Stage 5" to lower "Ordovician Stage 6") (Verschaeve, 2004 ms; Zalasiewicz et al., 2004).

Correlation with northern Gondwana is less straightforward. By the lack of other well-dated fossil groups, the robusta Biozone is rather poorly dated and placed together with the underlying $F$. tanvillensis Biozone in the post early Harnagian-pre-Onnian interval (upper "Stage 5"-lower to middle "Stage 6") (Paris, 1990). Webby et al. (2004) however place the robusta Biozone in the lower to middle "Stage 6".

The Vitrival-Bruyère Formation in the Rue de Courrière section is younger than in the type section. As mentioned above, Billiaert $(2000 \mathrm{~ms})$ found Laufeldochitina stentor in the type section. In the Fågelsång GSSP section (southern Sweden, Baltica) for the base of the Upper Ordovician, Vandenbroucke (2004) showed that the L. stentor Biozone is present from the Hustedograptus teretiusculus graptolite Biozone (upper Darriwilian) in to the lower part of the Nematograptus gracilis graptolite Biozone, the base of which indicates the base of the Upper Ordovician (Webby, 1998). In Baltica, the stentor Biozone corresponds to the late Uhaku (upper Darriwilian) and the Kukruse (lower "Ordovician Stage 5") (Nõlvak and Grahn, 1993). At least a part of the Vitrival-Bruyère Formation in its type section thus corresponds to the upper Darriwilian or lower "Ordovician Stage 5". It is hence possible that the base of the Upper Ordovician is situated in this section.

From JVM 03-133 on, the upper part of the VitrivalBruyère Formation, to JVM 03-94, the lower part of the Fosses Formation (Bois de Presles Member), the fungiformis Biozone is most probably present. As recently shown by Vandenbroucke et al. (2005), the fungiformis Biozone is present in the graptolite-bearing Pus Gill and the type Ashgill area sections (U.K.) from the upper part of the Onnian (uppermost Caradoc) to the basal part of the Cautleyan (lower Ashgill), thus crossing the Caradoc-Ashgill boundary. It corresponds in Baltoscandia to the late Oandu-early Vormsi times (formerly supposed to be late Caradoc; Nõlvak and Grahn, 1993).

If we assume the presence of $C$. incerta Eisenack, 1962 in the basal part of the Fosses Formation, a part of the Baltoscandian angusta Subbiozone is recognised and a pre-mid Rakvere (thus a late Oandu to early Rakvere) 
age for the upper part of the Vitrival-Bruyère Formation can be deduced. The boundary between the VitrivalBruyère and the Fosses Formation would than lie within the late Oandu-early Rakvere time span (supposed to be late Caradoc). This is apparently in contradiction to Lespérance and Sheehan (1987) and Sheehan (1987), who only found a pre-Hirnantian Ashgill brachiopod and trilobite fauna in the Fosses Formation. However, the stratigraphical position of their samples is poorly known and it is probable that they did not sample the basal-most part of the Fosses Formation. Furthermore, Vandenbroucke et al. (2005) found $C$. incerta? Eisenack, 1962 in the upper Onnian (uppermost Caradoc) and the lower Pusgillian of the Pus Gill and the type Ashgill sections. Specimens herein are very comparable to the specimens described by Vandenbroucke et al. (2005) and hence we can assume an upper Onnian to lower Pusgillian age for the boundary.

The bergstroemi Biozone is probably present in JVM 03-092 (Bois de Presles Member). In Baltoscandia, it corresponds to the late Vormsi-early Pirgu time (Nõlvak and Grahn, 1993). In the type Ashgill area, it is illconstrained but it certainly comprises at least the upper part of the Cautleyan (Vandenbroucke et al., 2005).

The upper part of the Bois de Presles Member and the lower part of the Faulx-les-Tombes Member can be dated as ?late Cautleyan-early Rawtheyan by correlation with the type Ashgill area (Vandenbroucke et al., 2005 ) by means of the rugata Biozone.

The upper part of the Faulx-les-Tombes Member is dated as late Rawtheyan by correlating the umbilicata Biozone with the type Ashgill area (Vandenbroucke et al., 2005).

\section{Lithofacies differences within the Fosses Formation (Fig. 5)}

Some of the biozones recognised in this study are also found in Sart-Eustache, in the allochtonous Puagne Inlier, western part of the Condroz Inlier (Fig. 1). The latter location lies $20 \mathrm{~km}$ west of the Faulx-les-Tombes area, but came originally from a locality several tens of kilometers to the south of Sart-Eustache and was brought to its present position by a Variscan thrust fault. In SartEustache, the bergstroemi, rugata and umbilicata Biozones where found in the bioturbated, macrofossiliferous, calcareous or decalcified shale to siltstone of the Bois de Presles Member (Vanmeirhaeghe and Verniers, 2004). Only the uppermost occurrence of Bursachitina umbilicata Vandenbroucke et al., 2005 was found to occur in mottled siltstone (Faulx-les-Tombes Member) (Vanmeirhaeghe and Verniers, 2004). The fungiformis
Biozone was not found in Sart-Eustache, indicating that the basal part of the Bois de Presles Member is missing (Fig. 5).

In the Faulx-les-Tombes area, the bergstroemi (?) and the rugata Biozones were also found in the Bois de Presles Member, but a part of the rugata and the umbilicata Biozone were found in the Faulx-les-Tombes Member. This implies facies differences between the central part of the Condroz Inlier and the Puagne Inlier and diachronism of the boundary between the Bois de Presles and the Faulx-les-Tombes members. As shown by brachiopod evidence (Sheehan, 1987), a BA 4-5 position was found from the Bois de Presles Member in all Condroz Inlier localities, including a level slightly below the rugata Biozone in Sart-Eustache. In contrast to this, a BA 5-6 position was obtained from brachiopod data from the Faulx-les-Tombes Member from the Rue du Bois Grand Pré section. This sample is situated in the rugata Biozone $55 \mathrm{~m} \mathrm{SW}$ of the crossroad (see Fig. 2). Hence, it is probable that at the same time, sedimentation of calcareous siltstone took place on a rather deep shelf in the western part of the Condroz

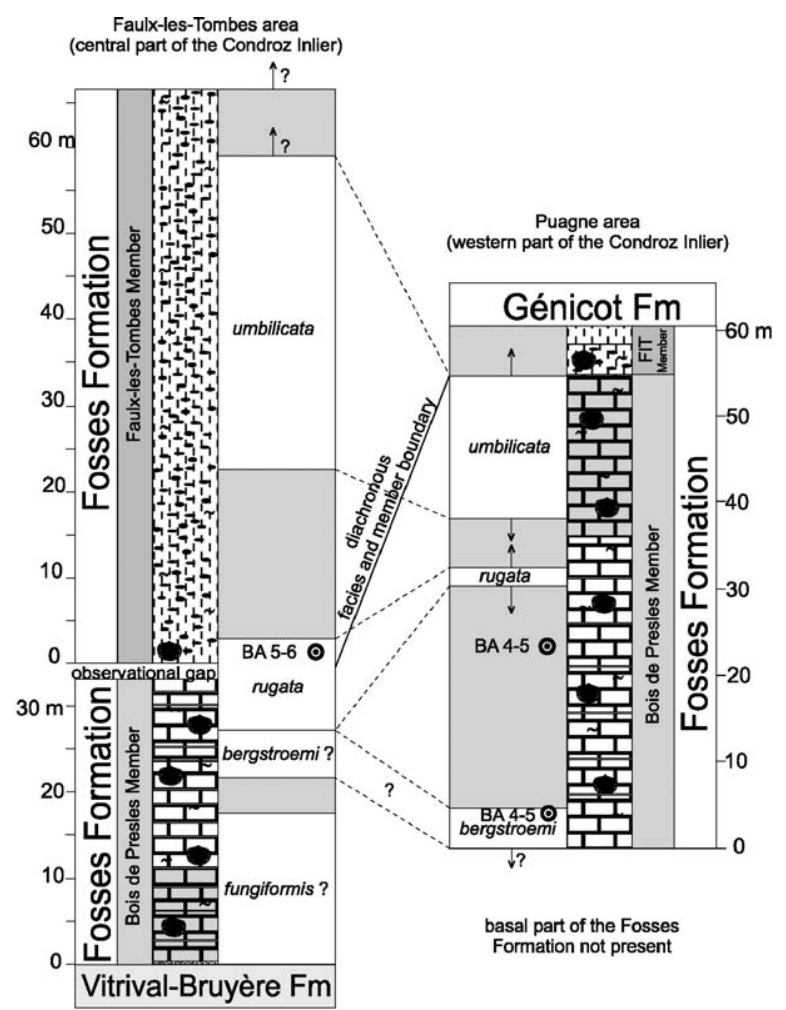

Fig. 5. Correlation of the central and the western part of the Condroz Inlier by means of chitinozoan biozones. The correlation makes clear the diachronism of the boundary between both members of the Fosses Formation. For explanation see text. For legend see Fig. 4. FlT: Faulxles-Tombes Member. 
Inlier, while in the central part, there was deposition of mottled siltstone on a deeper shelf position. Oxic conditions were present at the sediment-water interface by the time of deposition, as indicated by the presence of many ichnofossils in the Fosses Formation.

\section{Conclusions}

Correlation with the Baltoscandian chitinozoan biozones and the Avalonian Pus Gill and type Ashgill sections allows accurate dating of the Upper Ordovician Condroz Inlier deposits. In the Faulx-les-Tombes area, the Vitrival-Bruyère Formation has probably a Keila to early Oandu age (early "Ordovician Stage 6"), except for the uppermost part, which can probably be dated as late Oandu. The boundary between the Vitrival-Bruyère Formation and the Fosses Formation is placed in the upper Onnian (uppermost Caradoc)Pusgillian (lowermost Ashgill) interval. The Bois de Presles Member of the Fosses Formation is then assigned to the upper Onnian-lower Rawtheyan interval. The observed part of the Faulx-les-Tombes Member of the Fosses Formation has a lower to upper Rawtheyan age.

In its type section, the Vitrival-Bruyère Formation is dated as late Darriwilian to early "Ordovician stage 5". This implicates that the Vitrival-Bruyère Formation, formerly thought to be restricted to the foliaceus Biozone or situated around it (Verniers et al., 2001), spans a much larger time interval, i.e. from the late Darriwilian to the late Onnian-Pusgillian (early Ashgill). The upper part of this formation (studied herein) is characterised by many thin sandstone intercalations, in contrast to the type section, which represents more basal parts of the formation, where only few, but very thick (up to $2.50 \mathrm{~m}$ ), sandstone beds occur.

Several matrix-supported conglomerates were found in the upper part of the Vitrival-Bruyère Formation and the very base of the Fosses Formation. Together with the chitinozoan data, this questions the interpretation of the basal matrix-supported conglomerate of the Fosses Formation as being a basal conglomerate overlying an unconformity. If a hiatus is present, it is a small one and than it has a maximal importance spanning the upper Onnian-lower Pusgillian interval.

Correlation of the Faulx-les-Tombes and the SartEustache areas allows the recognition of facies and depth differences between the western and the central part of the Condroz Inlier. Moreover, the diachronic character of the boundary between the Bois de Presles and the Faulxles-Tombes members becomes clear. In the western part, a bioturbated, macrofossil-bearing and often calcareous siltstone facies is deposited until the late Rawtheyan, when onset of mottled siltstone deposition starts. In the central part, the former facies deposition ceases already in the early Rawtheyan and the deposition of mottled siltstone continues trough whole the rest of the Rawtheyan, resulting in a much more thick (at least $65 \mathrm{~m}$ in opposition to $2 \mathrm{~m}$ ) Faulx-les-Tombes Member in the central part. Data, presented herein, combined with brachiopod evidence from Sheehan (1987), show also a probably deeper basin in the central part of the Condroz Inlier in at least early Rawtheyan time.

\section{Acknowledgements}

The author is grateful to Yngve Grahn, an anonymous reviewer, Gary Mullins and Thomas Servais for valuable comments and a careful reading of the manuscript. Jacques Verniers is thanked for help on the field, discussion and for reading the manuscript, Thijs Vandenbroucke for chitinozoan discussions, Sabine Vancauwenberghe for help in processing the samples. The author thanks Siska Valcke for help with the figures. Special thanks go to the Grossi family (Faulx-lesTombes) for their hospitality and the pleasant stay. This work is a contribution to the IGCP 503 project (Ordovician Palaeogeography and Palaeoclimate) and the FWO project G.0094.01 (Tectonics of the Early Palaeozoic basin development in NW Europe: basin analysis and magnetic fabric analysis in the Belgian Caledonides).

\section{Appendix A}

Sample localities

JVM 03-19: Fosses Formation, Faulx-les-Tombes Member; Rue du Bois Grand-Pré section, circa $50.0 \mathrm{~m} \mathrm{SW}$ of the crossroad with the N 942.

JVM 03-20: Fosses Formation, Faulx-les-Tombes Member; Rue du Bois Grand-Pré section, $50.9 \mathrm{~m} \mathrm{SW}$ of the crossroad with the N 942.

JVM 03-21: Fosses Formation, Faulx-les-Tombes Member; Rue du Bois Grand-Pré section, $98.3 \mathrm{~m} \mathrm{SW}$ of the crossroad with the N 942. JVM 03-22: Fosses Formation, Faulx-les-Tombes Member; Rue du Bois Grand-Pré section, $122.7 \mathrm{~m} \mathrm{SW}$ of the crossroad with the N 942.

JVM 03-65: Fosses Formation, Faulx-les-Tombes Member; Rue du Bois Grand-Pré section, $43.75 \mathrm{~m} \mathrm{SW}$ of the crossroad with the N 942.

JVM 03-66: Fosses Formation, Faulx-les-Tombes Member; Rue du Bois Grand-Pré section, $50.0 \mathrm{~m}$ SW of the crossroad with the N 942.

JVM 03-70: Fosses Formation, Faulx-les-Tombes Member; Rue du Bois Grand-Pré section, $75.5 \mathrm{~m}$ SW of the crossroad with the N 942.

JVM 03-71: Fosses Formation, Faulx-les-Tombes Member; Rue du Bois Grand-Pré section, $87.2 \mathrm{~m} \mathrm{SW}$ of the crossroad with the N 942. 
JVM 03-74: Fosses Formation, Faulx-les-Tombes Member; Rue du Bois Grand-Pré section, $110.1 \mathrm{~m} \mathrm{SW}$ of the crossroad with the N 942.

JVM 03-76: Fosses Formation, Faulx-les-Tombes Member; Rue du Bois Grand-Pré section, $127.7 \mathrm{~m} \mathrm{SW}$ of the crossroad with the N 942.

JVM 03-77: Fosses Formation, Faulx-les-Tombes Member; Rue du Bois Grand-Pré section, 137.1 to $137.3 \mathrm{~m} \mathrm{SW}$ of the crossroad with the N 942.

JVM 03-78: Fosses Formation, Faulx-les-Tombes Member; Rue du Bois Grand-Pré section, 144.2 to $144.4 \mathrm{~m} \mathrm{SW}$ of the crossroad with the N 942.

JVM 03-79: Fosses Formation, Faulx-les-Tombes Member; Rue du Bois Grand-Pré section, 159.0 to $159.2 \mathrm{~m} \mathrm{SW}$ of the crossroad with the N 942.

JVM 03-80: Fosses Formation, Faulx-les-Tombes Member; Rue du Bois Grand-Pré section, $181.2 \mathrm{~m} \mathrm{SW}$ of the crossroad with the $\mathrm{N}$ 942.

JVM 03-83: Fosses Formation, Faulx-les-Tombes Member; Rue du Bois Grand-Pré section, $211.7 \mathrm{~m}$ to $211.8 \mathrm{~m} \mathrm{SW}$ of the crossroad with the N 942.

JVM 03-84: Fosses Formation, Faulx-les-Tombes Member; Rue du Bois Grand-Pré section, $222.7 \mathrm{~m}$ to $222.8 \mathrm{~m} \mathrm{SW}$ of the crossroad with the N 942.

JVM 03-85: Fosses Formation, Faulx-les-Tombes Member; E brook section, $104 \mathrm{~m} \mathrm{SW}$ of the crossroad with the $\mathrm{N} 942,9 \mathrm{~m}$ downhill, at the southern bank of the Ruisseau du Bois d'Arville.

JVM 03-88: Fosses Formation, Faulx-les-Tombes Member; E brook section, $29 \mathrm{~m} \mathrm{SW}$ of JVM 03-85, at the southern bank of the Ruisseau du Bois d'Arville.

JVM 03-89: Fosses Formation, Faulx-les-Tombes Member; E brook section, 35.7 to $35.8 \mathrm{~m} \mathrm{SW}$ of JVM $03-85$, at the southern bank of the Ruisseau du Bois d'Arville.

JVM 03-91: Fosses Formation, Bois de Presles Member; Rue de Courrière section, western slope, $121.2 \mathrm{~m} \mathrm{~N}$ of the crossroad with the Rue du Bois Grand Pré.

JVM 03-92: Fosses Formation, Bois de Presles Member; Rue de Courrière section, western slope, 127.6 to $127.7 \mathrm{~m} \mathrm{~N}$ of the crossroad with the Rue du Bois Grand Pré.

JVM 03-94: Fosses Formation, Bois de Presles Member; Rue de Courrière section, western slope, $134.5 \mathrm{~m} \mathrm{~N}$ of the crossroad with the Rue du Bois Grand Pré.

JVM 03-95: Fosses Formation, Bois de Presles Member; Rue de Courrière section, western slope, 140.6 to $140.7 \mathrm{~m} \mathrm{~N}$ of the crossroad with the Rue du Bois Grand Pré.

JVM 03-96: Fosses Formation, Bois de Presles Member; Rue de Courrière section, western slope, 146.2 to $146.3 \mathrm{~m} \mathrm{~N}$ of the crossroad with the Rue du Bois Grand Pré.

JVM 03-99: Vitrival-Bruyère Formation; Rue de Courrière section, western slope, 159.2 to $159.3 \mathrm{~m} \mathrm{~N}$ of the crossroad with the Rue du Bois Grand Pré.

JVM 03-101: Vitrival-Bruyère Formation; Rue de Courrière section, western slope, 167.0 to $167.1 \mathrm{~m} \mathrm{~N}$ of the crossroad with the Rue du Bois Grand Pré.

JVM 03-103: Vitrival-Bruyère Formation; Rue de Courrière section, western slope, $178.5 \mathrm{~m} \mathrm{~N}$ of the crossroad with the Rue du Bois Grand Pré.

JVM 03-104: Vitrival-Bruyère Formation; Rue de Courrière section, western slope, 182.4 to $182.5 \mathrm{~m} \mathrm{~N}$ of the crossroad with the Rue du Bois Grand Pré.
JVM 03-105: Vitrival-Bruyère Formation; Rue de Courrière section, western slope, 186.7 to $186.8 \mathrm{~m} \mathrm{~N}$ of the crossroad with the Rue du Bois Grand Pré

JVM 03-106: Vitrival-Bruyère Formation; Rue de Courrière section, western slope, $195.2 \mathrm{~m} \mathrm{~N}$ of the crossroad with the Rue du Bois Grand Pré.

JVM 03-109: Vitrival-Bruyère Formation; Rue de Courrière section, western slope, 203.25 to $203.35 \mathrm{~m} \mathrm{~N}$ of the crossroad with the Rue du Bois Grand Pré.

JVM 03-110: Vitrival-Bruyère Formation; Rue de Courrière section, western slope, $207.9 \mathrm{~m} \mathrm{~N}$ of the crossroad with the Rue du Bois Grand Pré

JVM 03-112: Vitrival-Bruyère Formation; Rue de Courrière section, western slope, 220.1 to $220.3 \mathrm{~m} \mathrm{~N}$ of the crossroad with the Rue du Bois Grand Pré.

JVM 03-113: Vitrival-Bruyère Formation; Rue de Courrière section, western slope, $220.5 \mathrm{~m} \mathrm{~N}$ of the crossroad with the Rue du Bois Grand Pré.

JVM 03-115: Vitrival-Bruyère Formation; Rue de Courrière section, western slope, $235.0 \mathrm{~m} \mathrm{~N}$ of the crossroad with the Rue du Bois Grand Pré.

JVM 03-116: Vitrival-Bruyère Formation; Rue de Courrière section, western slope, $243.6 \mathrm{~m} \mathrm{~N}$ of the crossroad with the Rue du Bois Grand Pré.

JVM 03-117: Fosses Formation, Faulx-les-Tombes Member; W brook section, $33 \mathrm{~m}$ E of the bridge over the Ruisseau du Bois d'Arville, in the southern brook bank.

JVM 03-120: Fosses Formation, Faulx-les-Tombes Member; W brook section, $62 \mathrm{~m}$ E of the bridge over the Ruisseau du Bois d'Arville, in the southern brook bank.

JVM 03-121: Fosses Formation, Faulx-les-Tombes Member; W brook section, $70 \mathrm{~m}$ E of the bridge over the Ruisseau du Bois d'Arville, in the northern brook bank.

JVM 03-125: Fosses Formation, Bois de Presles Member; Rue de Courrière section, western slope, $117.0 \mathrm{~m} \mathrm{~N}$ of the crossroad with the Rue du Bois Grand Pré.

JVM 03-128: Vitrival-Bruyère Formation; Rue de Courrière section, eastern slope, $154.1 \mathrm{~m} \mathrm{~N}$ of the crossroad with the Rue du Bois Grand Pré.

JVM 03-132: Vitrival-Bruyère Formation; Rue de Courrière section, eastern slope, $158.2 \mathrm{~m} \mathrm{~N}$ of the crossroad with the Rue du Bois Grand Pré.

JVM 03-133: Vitrival-Bruyère Formation; Rue de Courrière section, eastern slope, $156.3 \mathrm{~m} \mathrm{~N}$ of the crossroad with the Rue du Bois Grand Pré.

JVM 03-136: Fosses Formation, Bois de Presles Member; Rue de Courrière section, eastern slope, $153.5 \mathrm{~m} \mathrm{~N}$ of the crossroad with the Rue du Bois Grand Pré.

\section{References}

Billiaert, B., 2000. Kartering, lithostratigrafie en biostratigrafie met Chitinozoa van de Ordovicium-Siluur typesecties rond Fosses (westelijke Condroz-strook). Unpublished M.Sc. thesis, Laboratorium voor Paleontologie, Universiteit Gent, 83 pp.

Bulman, O.M.B., 1950. On some Ordovician graptolite assemblages of Belgium. Bull. Inst. R. Sci. Nat. Belg. 26 (5), 1-8.

De Geest, P., 1998. Het venster van Fond d'Oxhe (OrdoviciumSiluur): kartering, lithostratigrafie en biostratigrafie met Chitinozoa. Unpublished M. Sc. thesis, Laboratorium voor Paleontologie, Universiteit Gent, 96 pp. 
Eisenack, A., 1931. Neue Mikrofossilien des Baltischen Silurs, I. Palaeontol. Z. 13 (1-4), 74-118.

Eisenack, A., 1937. Neue Mikrofossilien des Baltischen Silurs. IV. Palaeontol. Z. 19 (1-4), 217-243.

Eisenack, A., 1955. Neue Chitinozoen aus dem Silur des Baltikums und dem Devon der Eifel. Senckenb. Lethaea 36 (5/6), 311-319.

Eisenack, A., 1959. Neotypen Baltischer Silur-Chitinozoen und neue Arten. Neues Jahrbuch für Geologie und Paläontologie. Abhandlungen 108 (1), 1-20.

Eisenack, A., 1962. Neotypen baltischer Silur-Chitinozoen und neue Arten. Neues Jahrbuch für Geologie und Paläontologie. Abhandlungen 114 (3), 291-316.

Eisenack, A., 1972. Chitinozoen und andere Mikrofossilien aus der Bohrung Leba, Pommern. Palaeontogr., Abt. A 140, 64-86.

Jansonius, J., 1964. Morphology and classification of some Chitinozoa. Bull. Can. Pet. Geol. 12 (4), 901-918.

Jenkins, W.A.M., 1970. Chitinozoa from the Ordovician Sylvan shale of the Arbuckle Mountains, Oklahoma. Palaeontology 13 (2), 261-288.

Lassine, A., 1913a. Sur les gites fossilifères du silurien de la planchette de Tamines Fosse. Bull. Soc. Belg. Géol. Paléontol. Hydrol. 27, $72-76$.

Lassine, A., 1913b. Quelques failles du Silurien du Bois de Presles. Ann. Soc. Géol. Belg. 41, B 50.

Lassine, A., 1914a. Quelques remarques relatives au Silurien de Vitrival. Ann. Soc. Géol. Belg. 41, B 156-B 157.

Lassine, A., 1914b. Nouvelle communication relative au Silurien de l'Entre-Sambre-et-Meuse (planchette Tamines-Fosse). Ann. Soc. Géol. Belg. 41, B 179-B 180.

Laufeld, S., 1967. Caradocian Chitinozoa from Dalarna, Sweden. Geol. Fören. Stockh. Förh. 89, 275-349.

Lespérance, P.J., Sheehan, P.M., 1987. Trilobites et Brachiopodes ashgilliens (Ordovicien supérieur) de 1'“Assise" de Fosse, Bande de Sambre-Meuse (Belgique). Bull. Inst. R. Sci. Nat. Belg., Sci. Terre 57, 91-123.

Maes, G., Rickards, B., Rombouts, L., Vandevelde, N., 1978. Silurian formations between Neuville-sous-Huy and Ombret: their correlation, age and structure. Ann. Soc. Géol. Belg. 101, 31-36.

Maillieux, E., 1913. Quelques mots sur l'état actuel des connaissances relatives au terrains siluriens de la Belgique. Bull. Soc. Belg. Géol., Paléontol. Hydrol. 27, 76-82.

Maillieux, E., 1926. Remarques sur l'Ordovicien de la Belgique. Bull. Soc. Belg. Géol., Paléontol. Hydrol. 36, 67-85.

Maillieux, E., 1933. Terrains, roches et fossiles de la Belgique, 2iéme édition. Publications du Musée Royal d'Histoire naturelle de Belgique, Bruxelles, 217 pp.

Malaise, C., 1909a. Echelle stratigraphique du Silurien de Belgique et âge géologique des schistes noirs de Mousty. Ann. Soc. Géol. Belg. 36, M 31-M 39.

Malaise, C., 1909b. Modifications de l'échelle stratigraphique du Silurien de Belgique. Bull. Soc. Belg. Géol., Paléontol. Hydrol. 23, 6-8.

Malaise, C., 1910. Stratigraphie du Massif Cambro-Silurien du Brabant. Ann. Soc. Géol. Belg. 38, 136-142.

Martin, F., 1969. Les acritarches de l'Ordovicien et du Silurien belge. Détermination et valeur stratigraphique. Mém. Inst. R. Sci. Nat. Belg. 160, 1-176.

Michot, P., 1928. La bande silurienne de Sambre-et-Meuse entre Fosse et Boufioulx. Ann. Soc. Géol. Belg. 51, M 57-M 103.

Michot, P., 1934. La stratigraphie du Silurien de la bande Sambre-etMeuse. Mém. Acad. R. Belg. , Cl. Sci. 13 (2), 1-108.
Michot, P., 1944. La bande silurienne de Sambre-et-Meuse entre Fosse et la Meuse. Ann. Soc. Géol. Belg. 68, B 75-B 112.

Michot, P., 1954. Le Silurien. In: Fourmarier, P. (Ed.), Prodrôme d'une description géologique de la Belgique. Liège, Carmanne-Vaillant, pp. $39-82$.

Neville, R.S.W., 1974. Ordovician Chitinozoa from western Newfoundland. Rev. Palaeobot. Palynol. 18 (3-4), 187-221.

Nõlvak, J., Grahn, Y., 1993. Ordovician chitinozoan zones from Baltoscandia. Rev. Palaeobot. Palynol. 79, 245-269.

Paris, F., 1981. Les Chitinozoaires dans le Paléozoïque du SudOuest de l'Europe (Cadre géologique - Etude systématique Biostratigraphie). Mém. Soc. Géol. Minéral. Bretagne 26, $1-412$.

Paris, F., 1990. The Ordovician chitinozoan biozones of the northern Gondwana domain. Rev. Palaeobot. Palynol. 66, 181-209.

Paris, F., Grahn, Y., Nestor, V., Lakova, I., 1999. A revised chitinozoan classification. J. Paleontol. 73 (4), 549-570.

Regnell, G., 1951. Revision of the Caradocian-Ashgillian cystoid fauna of Belgium with notes on isolated pelmatozoan stem fragments. Mém. Inst. R. Sci. Nat. Belg. 120, 1-47.

Schallreuter, R., 1963. Neue Chitinozoen aus ordovizischen Geschieben und Bemerkungen zur Gattung Illichitina. Paläontol. Abh. I (B-4), 391-405.

Servais, T., Maletz, J., 1992. Lower Llanvirn (Ordovician) graptolites and acritarchs from the "Assise de Huy", Bande de Sambre-etMeuse, Belgium. Ann. Soc. Géol. Belg. 115, 265-285.

Sheehan, P.M., 1987. Late Ordovician (Ashgillian) Brachiopods from the region of the Sambre and Meuse rivers, Belgium. Bull. Inst. R. Sci. Nat. Belg., Sci. Terre 57, 5-81.

Stainier, A., 1926. Observation sur la pointe silurienne de Puagne. Bull. Soc. Belg. Géol., Paléontol. Hydrol. 36, 113-115.

Tourneur, F., Vanguestaine, M., Buttler, C., Mamet, B., Mouravieff, N., Poty, E., Préat, A., 1993. A preliminary study of Ashgill carbonate beds from the lower part of the Fosses Formation (Condroz, Belgium). Geol. Mag. 130 (5), 673-679.

Vandenbroucke, T., 2004. Chitinozoan biostratigraphy of the Upper Ordovician Fagelsang GSSP, Scania, southern Sweden. Rev. Palaeobot. Palynol. 130, 217-239.

Vandenbroucke, T.R.A., Rickards, B., Verniers, J., 2005. Upper Ordovician Chitinozoan biostratigraphy from the type Ashgill Area (Cautley district) and the Pus Gill section (Dufton district, Cross Fell Inlier), Cumbria, Northern England. Geol. Mag. 142 (6), 783-807.

Vanmeirhaeghe, J., 2001. Litho-en biostratigrafie met Chitinozoa en sedimentologie van het Boven-Ordovicium in de heuvel Tier d'Olne (Ombret, Condrozstrook). Unpublished M.Sc. thesis, Laboratorium voor Paleontologie, Universiteit Gent, 150 pp.

Vanmeirhaeghe, J., 2002. Stratigraphy of the Fosses and Génicot Formations west of Fosses (Condroz Inlier, Belgium) by a chitinozoan study and re-evaluation of the Cocriamont conglomerate. Unpublished DEA thesis, Services associés de Paléontologie, Université de Liège, 103 pp.

Vanmeirhaeghe, J., Verniers, J., 2002. Biostratigraphy with chitinozoans and lithostratigraphy of the Tier d'Olne hill (Ombret, Condroz Inlier, Belgium). In: Degryse, P., Sintubin, M. (Eds.), Contributions to the geology of Belgium and Northwest Europe. Proceedings of the first Geologica Belgica International Meeting, 11-15 September 2002. Aardkundige Mededelingen, vol. 12, pp. $85-88$.

Vanmeirhaeghe, J., Verniers, J., 2004. Chitinozoan bio- and lithostratigraphical study of the Ashgill Fosses and Génicot 
Formations (Condroz Inlier, Belgium). Rev. Palaeobot. Palynol. 130, 241-267.

Verniers, J., Herbosch, A., Vanguestaine, M., Geukens, F., Delcambre, B., Pingot, J.L., Bellanger, I., Hennebert, M., Debacker, T., Sintubin, M., De Vos, W., 2001. Cambrian-Ordovician-Silurian lithostratigraphic units (Belgium). Geol. Belg. 4/1-2, 1-28.

Verschaeve, D., 2004. Biostratigrafie met Chitinozoa van de GSSPkandidaat voor de basis van "Etage Zes" van het Ordovicium, in Hartfell Score (Southern Uplands, Schotland). Unpublished M.Sc. thesis, Laboratorium voor Paleontologie, Universiteit Gent.
Webby, B.D., 1998. Steps towards a global standard for Ordovician stratigraphy. Newsl. Stratigr. 36 (1), 1-33.

Webby, B.D., Paris, F., Droser, M.L., Percival, I.G., 2004. The Great Ordovician Biodiversification Event. Columbia University Press, New York.

Zalasiewicz, J. Rushton, A., Vandenbroucke, T., Verniers, J., Stone, P., Floyd, J., 2004. Submission of Hartfell Score (south Scotland) as a GSSP for the base of the middle stage of the Upper Ordovician Series. ISOS website. http://www.ordovician.cn/down/HartfellGSSP. pdf. 